\title{
Vegetation dynamics following seasonal fires in mixed mesquite/acacia savannas
}

\author{
M. KEITH OWENS, J.W. MACKLEY, AND C.J. CARROLL
}

Authors are Professor and former Research Technicians with Texas Agricultural Experiment Station, 1619 Garner Field Rd., Uvalde, Tex, 78801. Send reprint requests to MKOwens at m-owens@tamu.edu.

\section{Abstract}

Fires were once a natural part of most savanna ecosystems, but lack of fine fuel and an active suppression policy have changed fire frequency and seasonality. Re-introducing fires to these systems has been touted as a cost-effective means to reduce woody cover while increasing herbaceous growth. We compared the effects of single, recurring annual, and biennial fires on the vegetation dynamics of a mixed mesquite/acacia (Prosopis/Acacia) savanna in southern Texas. Fires were conducted either during the growing season or the dormant season from 1991 through 1995. Some of the fire treatments were statistically unreplicated to permit a sufficient plot size for natural fire behavior. All plots showed a successional trajectory from short-grasses towards mid-grasses regardless of the fire season or frequency. The population size structure of perennial grasses was unaffected by the fires, with the basal area of most plants being less than $25 \mathrm{~cm}^{2}$. Forb diversity was high with over 100 different species identified in the experimental area. Forb composition, however, was unaffected by either the season or frequency of fire, but was related to the year of observation. Shrubs in this community typically sprout after disturbance, so little mortality was expected. The only observed mortality was of small shrubs or saplings (diameter $<3 \mathrm{~cm}$ ) and of large trees which had woodrat (Neotoma micropus) nests at the base. Reintroducing growing season fires into mesquite/mixed acacia shrublands did not conclusively alter plant community composition. Burning during the growing season when environmental conditions were hotter and drier did not accelerate succession toward grass-dominated communities.

Key Words: fire frequency, seasonality, prescribed burns, Prosopis glandulosa, Acacia, detrended correspondence analysis, ordination

The mixed mesquite/acacia (Prosopis/Acacia) savannas of southwestern North America have undergone a drastic change in physiognomy over the last 200 years. These previously open savannas are now dominated by low shrubs with a honey mesquite (Prosopis glandulosa. var. glandulosa Torr) overstory. Fires were once a natural occurrence in these savannas, but fire frequency has decreased due to reductions in fine fuel and to fire

Acknowledgements: Research was funded by the Texas Agricultural Experiment Station. We are grateful to D.E. Spalinger, D.E. Martin, R. Reynolds, and numerous undergraduate students who helped collect field data, and to C.A. Taylor, Jr. and R.K. Lyons for evaluating an earlier draft of the manuscript

Manuscript accepted 1 Nov. 01.
Resumen

Los incendios constituyeron un fenómeno natural en la mayoría de los ecosistemas de sabanas, pero dibido a la restricción de medidas de mantenimiento y a la falta de combustibles finos, han cambiado su frecuencia y estacionalidad. La reintroducción de incendios en estos sistemas ha sido considerada como una medida económicamente efectiva para reducir la vgetación leñosa y así aumentar la capa herbácea. Este estudio compara el efecto de diferentes frecuencias de incendios (anual, múltiples por año, a bianual) sobre la dinámica de la vegetación en una sabana constituida por una combinación de mesquite/acacia (Prosopis/Acacia) del sur de Tejas. Los incendios fueron realizados durante las estaciones de crecimiento o reposo durante 1991 a 1995. Para permitir un tamaño suficiente de las parcelas, algunos tratamientos no fueron repetidos estadísticamente. Todas las parcelas mostraron una trayectoria en sucesión de pastos bajo a pastos medianos, respuesta que fue independiente de la frecuencia o estacionalidad de los incendios. La estructura y tamano de la población de los pastos perennes no fueron afectados por los incendios, presentando la mayoría de las plantas un área basal menor a $25 \mathrm{~cm}^{2}$. La diversidad de pastos fue alta, con más de 100 especies identificadas en el área experimental. La composición de los pastos no fue afectada por la estacion o frecuencia de incendios, pero estuvo en relación con el año de observación. La comunidad arbustiva brotó después del fuego, no existiendo prácticamente mortalidad; sólo se observo mortalidad en los arbustos de menor porte (con diámetros $\leq 3 \mathrm{~cm}$ ) y en árboles de gran porte que tenían nidos de ratas (Neotoma micropus) en la base. La reintroducción de incendios durante el período de crecimiento vegetativo para la combinación arbustiva de mesquite/especies de acacia no alteró la composición de la comunidad de plantas. La realización de incendios durante el período de crecimiento, en condiciones ambientales de altas temperaturas y baja humedad, no aceleró el desarrollo de las comunidades herbáceas.

suppression policy. Where fires are used for brush management, prescribed burns are conducted during the cooler dormant season months when fire control is easier (Scifres and Hamilton 1993).

There is growing evidence in other ecosystems, however that frequency and seasonality of fires can affect fire intensity (Williams et al. 1999) and alter herbaceous species composition (Howe 1994, 1995, Tveten and Fonda 1999). Dormant season fires conducted in mesic communities of the northern Great Plains favor C4 grasses (Howe 2000) and forbs (Biondini et al. 1989) whereas growing-season fires promote C3 grasses (Howe $1995,2000)$. In xeric communities of desert grasslands, fires can 
shift the balance between black grama (Bouteloua eripoda torr.) and blue grama (Bouteloua gracilis (Kunth.) lag.ex griffths) within the herbaceous layer (Gosz and Gosz 1996).

There is little likelihood, however, that fires conducted during the dormant season will reduce the density and long-term cover of resprouting shrubs (Engle et al. 1991, Boo et al. 1997, Grice 1997, Pendergrass et al. 1998). A more realistic effect of fires may be a change in plant architecture. Low intensity dormant-season fires in mesquite communities of north Texas killed low branches on large shrubs or small trees while not affecting apical dominance, whereas high intensity summer fires killed more of the canopy resulting in basal sprouting and development of mesquite thickets (Ansley and Jacoby 1998).

The objectives of this study were to determine the impact of fire seasonality and fire frequency on plant community changes within mesquite/acacia shrublands. Successional trajectories of density and cover were modeled for shrubs, grasses and forbs through a series of annual and biennial seasonal fires. Changes in the basal area size classes of perennial grasses were determined after these fires to monitor population structure dynamics.

\section{Methods}

The study was conducted in a mesquite/mixed brush community on the Lyles Experimental Ranch near Uvalde, Tex $\left(29^{\circ} 03^{\prime} \mathrm{N}, 95^{\circ} 54^{\prime} \mathrm{W}\right)$. This area is semiarid with a mean annual precipitation (96 year record) of $61.7 \mathrm{~cm}$ distributed bimodally with peaks in May-June and September. Annual extremes over the 96 year period range from 23.6 to $114.4 \mathrm{~cm}$. Precipitation during the study was greater than average for 3 years $(1990,1992$, and 1994) and below average for 2 years (1991 and 1993, Fig. 1).

An 80-ha area was subdivided into 2 equal parts for growing season (July-August) or dormant season (January-February) prescribed fires. Each of these seasonal areas was further subdivided and randomly assigned to 1 of 3 treatments resulting in 13ha study plots. The first area was an unburned control, the second was burned on an annual cycle and the third was burned on a biennial cycle. The decision was made to create plots large enough for normal fire behavior although this design resulted in a non-replicated experiment. Statistical analyses, described in more detail in a

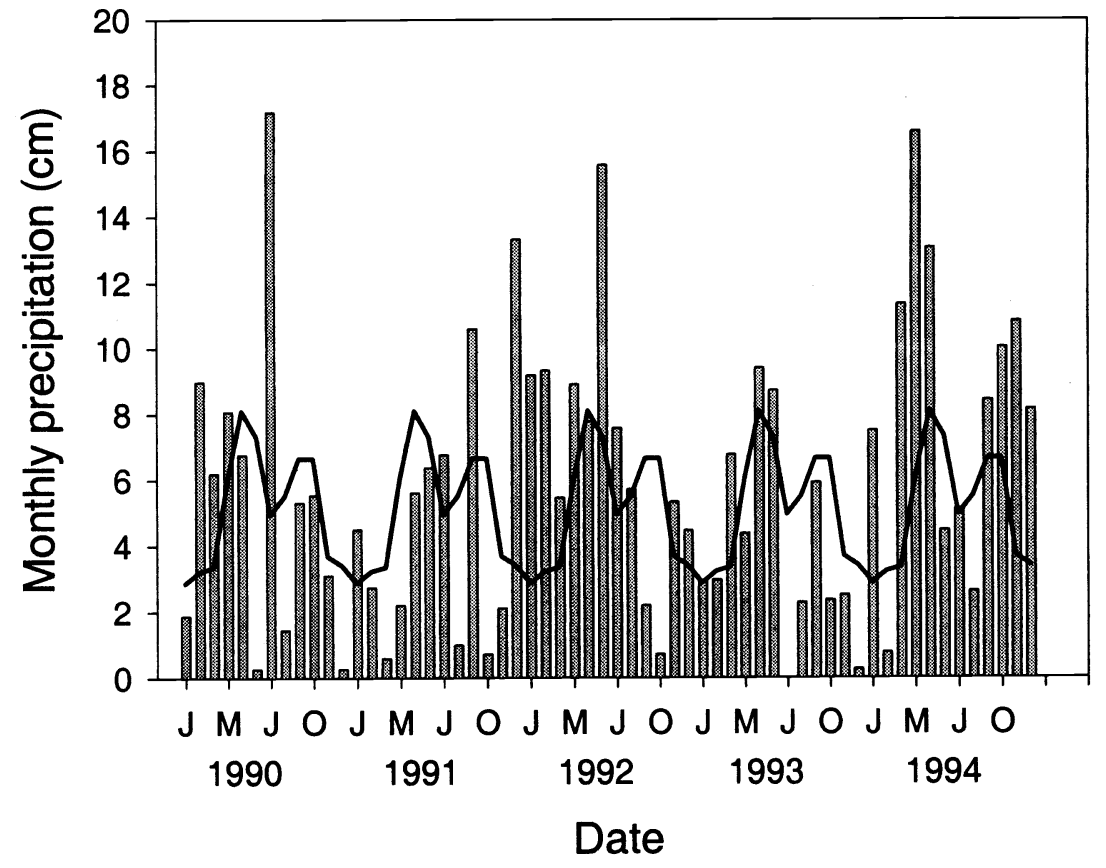

Fig. 1. Monthly precipitation (bars) from the Lyles Experimental Ranch for the duration of the study (1990-1994) and the long-term average (1904-1994, solid line) of the Uvalde, Tex. weather station approximately $30 \mathrm{~km}$ from the study site.

later section, used the techniques presented in Milliken and Johnson (1989) for planned, unreplicated experiments.

Prior to any burning, shrub and tree canopy cover was measured along 12 permanent $15-\mathrm{m}$ lines in each area (total $\mathrm{n}=$ 72) using the line intercept method (Canfield 1941). Grass density was measured in 30 permanent $1-\mathrm{m}^{2}$ plots within each treatment. The number of plants within each plot in 3 basal area cover classes $\left(<25,25-50\right.$, and $\left.>50 \mathrm{~cm}^{2}\right)$ were counted for each grass species. Density was used rather than canopy cover for the grasses to detect changes in plant size and fragmentation. Forb cover was estimated using Daubenmire frames $(20 \times 50 \mathrm{~cm})$ located in each corner of the permanent grass plots for a total of 120 forb plots in each of the treatment areas. All plots and transects were resampled annually in either June or July from 1990 through 1994. The sample in June 1990 served as the pre-burn sample for all plots. Nomenclature follows Hatch et al. (1990).

Livestock grazing on this site was discontinued in 1988 to allow an accumulation of fine fuel, and livestock were excluded for the duration of this study as well. Prior to the experiment, this pasture was used as a trap to hold a large number of animals for a short period of time. Potential stocking rate prior to this experiment was very low ( $>45$ acres per animal unit) due to heavy brush cover.
Environmental conditions during dormant-season (January-February) burns were air temperatures of $7-18^{\circ} \mathrm{C}$, wind speed of 1.3-4.5 $\mathrm{m} \mathrm{sec}^{-1}$ from the southeast, and relative humidity of $65-80 \%$. Growing season fires (July-August) were conducted with air temperatures of 35$40^{\circ} \mathrm{C}$, wind speed of $2.2-5.4 \mathrm{~m} \mathrm{sec}^{-1}$ from the southeast, and relative humidity of $20-50 \%$. Fine fuel on all sites ranged from 450 to $890 \mathrm{~kg} \mathrm{ha}^{-1}$ and was spatially discontinuous. Firelines were widened with backfires, and the main burns were conducted as headfires. All plots in the biennial cycle were burned twice, plots in the dormant season-annual cycle were burned 4 times, and plots in the growing seasonannual cycle were burned 3 times (Table 1). All permanent plots were inspected immediately after each fire to make sure they had burned, and if the area had not burned then new fires were started.

The trajectory of plant community changes within each of the 6 burn treatments was analyzed using detrended correspondence analysis (DECORANA) with the PC-ORD software package (MJM Software). This version of the PC-ORD program contained corrected algorithms to minimize distortion of the axes. Separate analyses were conducted for shrubs, grasses, and forbs because of the different sampling techniques used for each life form. Species with only 1 occurrence were deleted from the matrix prior to ordina- 
Table 1. Sampling and burning schedule within a mesquite/acacia shrubland in the Rio Grande Plains of Texas for different fire seasons and intervals.

\begin{tabular}{|c|c|c|c|c|c|c|c|c|c|c|}
\hline \multirow[t]{2}{*}{ Fire Season } & \multirow{2}{*}{$\begin{array}{l}\text { Fire } \\
\text { Interval }\end{array}$} & \multirow{2}{*}{$\frac{1990}{\text { Jun }}$} & \multicolumn{2}{|c|}{1991} & \multicolumn{2}{|c|}{1992} & \multicolumn{2}{|c|}{1993} & \multicolumn{2}{|c|}{1994} \\
\hline & & & Feb & Jun & $\overline{J a n}$ & Jul & Jan & Jul & Jan & Jul \\
\hline Growing & $\begin{array}{l}\text { Biennial } \\
\text { Annual } \\
\text { Control }\end{array}$ & $\begin{array}{l}S \\
S \\
S_{1}\end{array}$ & & $\begin{array}{l}S_{2,4,6} B \\
S_{2,4,6} B \\
S_{1,2,4,6}\end{array}$ & & $\begin{array}{l}S_{2,4,6} \\
S_{2,4,6} B \\
S_{2,4,6}\end{array}$ & & $\begin{array}{l}\mathrm{S}_{4,6} \mathrm{~B} \\
\mathrm{~S}_{4,6} \mathrm{~B} \\
\mathrm{~S}_{4,6}\end{array}$ & & $\begin{array}{l}\mathrm{S}_{6} \\
\mathrm{~S}_{6} \\
\mathrm{~S}_{6}\end{array}$ \\
\hline Dormant & $\begin{array}{l}\text { Control } \\
\text { Annual } \\
\text { Biennial }\end{array}$ & $\begin{array}{l}S_{1,3,5} \\
S_{1,3,5} \\
S_{1,3,5}\end{array}$ & $\begin{array}{l}\text { B } \\
\text { B }\end{array}$ & $\begin{array}{l}S_{1,2,3,5} \\
S_{1,3,5} \\
S_{1,3,5}\end{array}$ & B & $\begin{array}{l}S_{2,3,5} \\
S_{3,5} \\
S_{3,5}\end{array}$ & $\begin{array}{l}\text { B } \\
\text { B }\end{array}$ & $\begin{array}{l}S_{5} \\
S_{5} \\
S_{5}\end{array}$ & B & $\begin{array}{l}S_{5} \\
S_{5} \\
S_{5}\end{array}$ \\
\hline
\end{tabular}

$\mathrm{S}=$ Sampled, B = Burned, Subscripts refer to the ANOVA models described in the text.

tion, and rare species $(<10$ observations) were downweighted to minimize their impact on the ordination (Hill and Gauch 1980). The ordination of each treatment/year combination $(n=24)$ allowed the establishment of trajectories of species change through time (Abrahamson and Abrahamson 1996, Fuhlendorf and Smeins 1997).

Changes in the population structure of grasses in different basal area size classes were analyzed with a series of 6 separate analyses. These analyses were conducted to detect changes in the size class distribution of the grass community that may not be reflected in changes of total cover (e.g. total cover could be the same with many small plants or a few large plants). The first ANOVA tested for the effects of a single dormant-season fire by using plots from the unburned areas as replicated controls and the samples from June 1990 and June 1991 on the annual and biennial cycle dormant-season areas as replicated treatments (Table 1). The biennial cycle areas had been burned only once at this point so they could be used as a replicate plot of the annual burn. The statistical model used 2 replications, burn treatment (single or none), basal area cover classes and their interaction (error A) in the main model and the 2 observation times as a split plot (4-way interaction = error B). A split-plot model was used, rather than a repeated measures model, after statistical consultation and sphericity tests. The second ANOVA tested the effect of a single growing-season fire using the unburned control areas and the samples from June 1991 and July 1992 observations from the annual and biennial cycle areas within the growing-season fire area as the treatment (Table 1). The same statistical model was used as for the single dormant-season fires. All tests were conducted with a significance level of $\mathrm{P}<0.05$.

Logistical constraints in the amount of area available to burn and in field sam- pling time prevented true replication of the biennial burning treatments. Analysis of unreplicated experiments is possible if interaction terms are assumed to be zero and if higher order interactions are used as error terms (Milliken and Johnson 1989). Interpretation of the results should be done with care, and extrapolations should be performed with some trepidation (Mead 1988). The third ANOVA tested the effects of unburned, a single, and 2 consecutive dormant-season burns using samples from the control, annual and biennial cycle areas from June 1990 through July 1992 (Table 1). The statistical model used burn treatment (none, single or biennial), basal area cover classes and their interaction (error A) in the main model and the 2 observation times as a split plot (3-way interaction = error $\mathrm{B})$. A similar analysis (ANOVA 4) for growing season fires used samples from the control, annual, and biennial cycle areas from June 1991 through July 1993 (Table 1). Finally, the

Table 2. Mean percent cover of woody vegetation in a mesquite/mixed acacia shrubland in the Rio Grande Plains of Texas prior to implementing fire treatments in June 1990.

\begin{tabular}{|c|c|c|c|c|c|c|c|}
\hline \multirow[b]{3}{*}{ Species } & \multirow[b]{3}{*}{ Abbr. } & \multicolumn{3}{|c|}{ Dormant-Season } & \multicolumn{3}{|c|}{ Growing-Season } \\
\hline & & \multicolumn{3}{|c|}{ Fire Frequency } & \multicolumn{3}{|c|}{ Fire Frequency } \\
\hline & & Unburned & Annual & Biennial & Unburned & Annual & Biennial \\
\hline$\overline{\text { Acacia berlanderi }}$ & $\mathrm{ACBE}$ & 1.4 & 3.2 & 1.6 & 3.0 & 1.4 & 4.1 \\
\hline Acacia greggii & ACGR & 0.2 & 1.5 & 2.6 & 0.7 & 2.3 & 2.0 \\
\hline Acacia schaffneri & ACSC & 3.7 & 4.4 & 7.8 & 13.1 & 2.1 & 9.0 \\
\hline Acacia wrightii & ACWR & - & - & 0.1 & - & - & - \\
\hline Aloysia gratissima & ALGR & 4.3 & 1.5 & 1.6 & 2.1 & 0.6 & 2.3 \\
\hline Castela texanum & CATE & - & - & - & - & 0.4 & - \\
\hline Celtis pallida & CEPA & 0.1 & - & 1.2 & 0.8 & 0.1 & 2.7 \\
\hline Condalia ericoides & COER & - & 1.7 & - & - & - & - \\
\hline Condalia hookeri & $\mathrm{COHO}$ & 1.9 & - & 1.6 & 0.1 & 2.2 & 0.9 \\
\hline Colubrina texensis & COTE & 0.7 & 2.7 & 1.6 & 0.1 & - & - \\
\hline Diospyros texana & DITE & 1.8 & - & - & 0.3 & 1.1 & 0.1 \\
\hline Ephedra antisyphilitica & EPAN & 0.2 & - & 0.3 & 0.5 & - & 0.1 \\
\hline Guaiacum angustifolium & GUAN & 1.6 & 1.4 & 2.7 & 1.8 & 0.3 & 1.2 \\
\hline Leucophyllum frutescens & LEFR & - & - & - & - & 1.3 & - \\
\hline Lycium berlanderi & LYBE & 1.8 & 1.5 & 3.4 & 4.2 & 4.6 & 2.9 \\
\hline Lycium carolinianum & LYCA & - & - & 0.2 & - & - & 0.5 \\
\hline Parkinsonia texana & PATE & 0.2 & - & 0.3 & - & 0.3 & - \\
\hline Prosopis glandulosa & PRGL & 44.7 & 37.2 & 31.3 & 17.2 & 19.0 & 18.2 \\
\hline Rhus microphylla & RHMI & 0.8 & 0.5 & 2.4 & 1.8 & 3.1 & 1.6 \\
\hline Schaefferia cuneifolia & SCCU & 0.7 & 0.2 & 1.1 & 2.1 & 0.7 & 0.8 \\
\hline Yucca treculeana & YUTR & - & - & 0.2 & - & - & - \\
\hline Zizyphus obtusifolia & ZIOB & 0.7 & 0.2 & 0.6 & 0.1 & 0.3 & 0.9 \\
\hline Total & & 64.8 & 56.1 & 60.6 & 47.9 & 39.8 & 47.4 \\
\hline
\end{tabular}



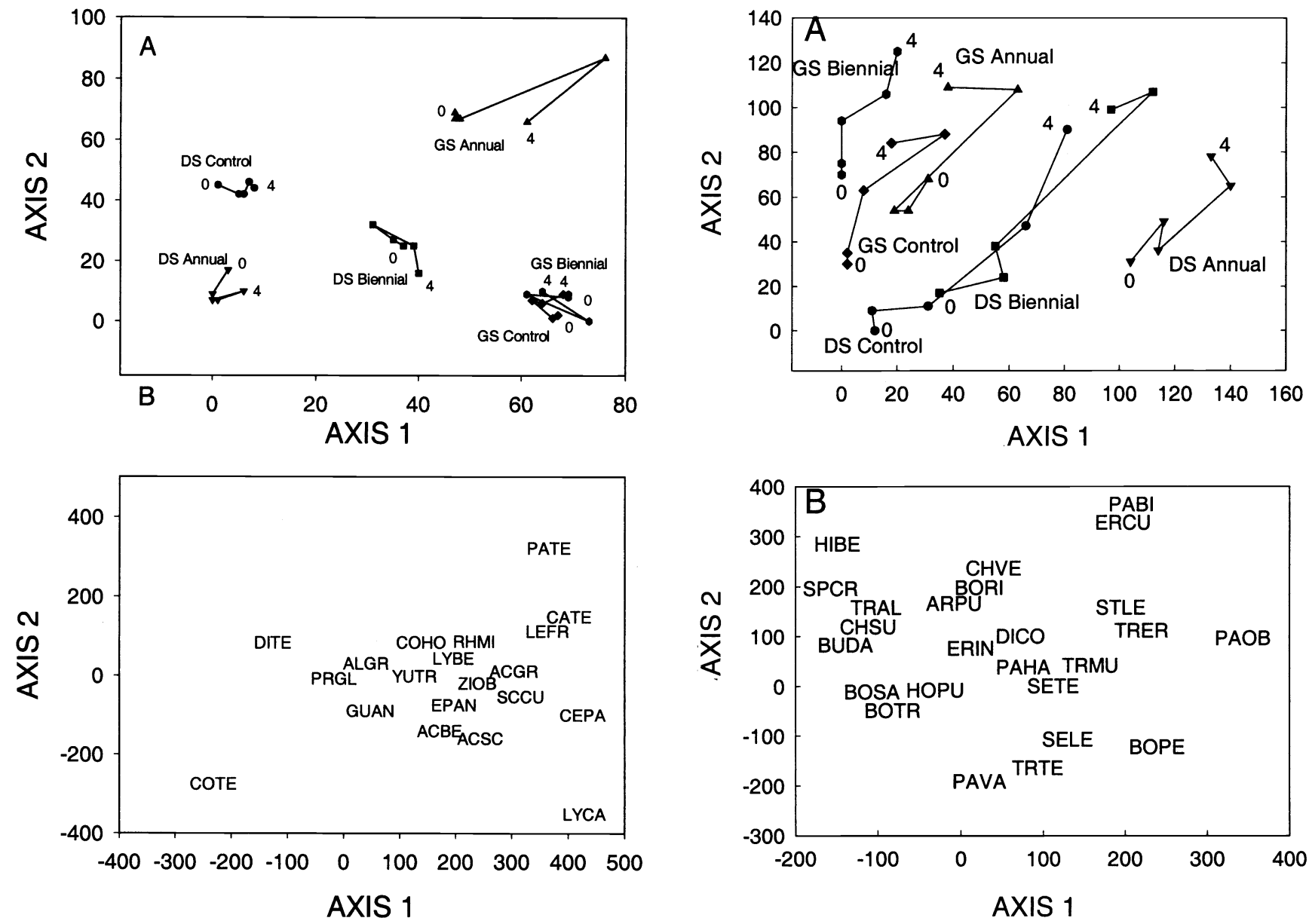

Fig. 2. Detrended correspondence analysis of shrub cover (A) and species distribution in the ordination space $(B)$ within a mesquite/mixed acacia shrubland in the Rio Grande Plains of Texas after growing-season (GS) and dormant-season (DS) fires. Numbers within the figure designate the year of observation beginning in 1990 and the lines represent the trajectory of change. Species acronyms are defined in Table 2.

Fig. 3. Detrended correspondence analysis of grass density (A) and species distribution in the ordination space (B) within a mesquite/mixed acacia shrubland in the Rio Grande Plains of Texas after growing-season (GS) and dormant-season (DS) fires. Numbers within the figure designate the year of observation beginning in 1990 and the lines represent the trajectory of change. Species acronyms are defined in Table 3.

effects of recurring annual versus recurring biennial fires were tested using the samples from June 1990 through July 1994 for the dormant season fires (ANOVA 5) and from June 1991 through July 1994 for the growing season fires (ANOVA6). No mean separation tests were planned with these analyses due to the lack of true replication.

\section{Results}

\section{Woody Vegetation}

Prior to the treatment application, 24 species of woody shrubs and trees with total cover ranging from 39.8 to $64.8 \%$ were identified within the 6 treatment areas (Table 2, shrubs with trace amounts $(<0.01 \%)$ not shown). Honey mesquite was the dominant tree on all sites with cover ranging from a high of nearly $44 \%$ on the dormant-season control area to a low of $17 \%$ on the growing-season control area. The most common shrub was twisted acacia (Acacia schaffneri (S. Wats) Herm. var bravoensis), while most other shrubs had less than $10 \%$ cover. Seven species appeared in only a single treatment area. Shrub and tree cover were not affected by treatments $(\mathrm{P}>0.1)$, so only the initial cover values are presented.

Although the treatment areas all started with slightly different species compositions, trajectories showed little change in the woody vegetation due to any of the burning frequencies or seasons (Fig 2A). The Axis 1 (eigenvalue $=0.105$, length $=$ 824) represented a gradient away from mesquite and Texas colubrina (Colubrina texana T.\&G.) and towards an increasing mixture of resprouting, medium-stature shrubs common on deep soils [guajillo (Acacia berlandieri Benth.), twisted acacia, and spiny hackberry (Celtis pallida Torr.)] (Fig 2B). Axis 2 (eigenvalue = 0.051 , length $=.742$ ) represented a gradient from the same medium-statured shrubs as in Axis 1 towards shrubs common on shallow soils which do not resprout [ceniza (Leucophyllum frutescens (Berl.) I.M. Johnst.)] or which resprout slowly [allthorn (Castela texanum (T.andG.) Rose), and Texas paloverde (Parkinsonia texana (Gray) S.Wats.)]. Small shrubs $(<0.5 \mathrm{~m}$ tall and $<2.5 \mathrm{~cm}$ diameter) were killed by both growing-season and dormant-season fires but the only mortality among mature trees occurred when woodrats (Neotoma micropus) nested at the base. The addition- 
Table 3. Grass density $\left(\# \mathbf{m}^{-2}\right)$ in a mesquite/mixed acacia shrubland in the Rio Grande Plains of Texas prior to prescribed fires (Year 0 in June 1990) and at the end of the study (Year 4 in July 1994).

\begin{tabular}{|c|c|c|c|c|c|c|c|c|c|c|c|c|c|}
\hline \multirow{3}{*}{$\begin{array}{l}\text { Fire Frequency } \\
\text { Year }\end{array}$} & \multirow[b]{3}{*}{ Abbr. } & \multicolumn{6}{|c|}{ Dormant-Season } & \multicolumn{6}{|c|}{ Growing-Season } \\
\hline & & \multicolumn{2}{|c|}{ Unburned } & \multicolumn{2}{|c|}{ Annual } & \multicolumn{2}{|c|}{ Biennial } & \multicolumn{2}{|c|}{ Unburned } & \multicolumn{2}{|c|}{ Annual } & \multicolumn{2}{|c|}{ Biennial } \\
\hline & & 0 & 4 & 0 & 4 & $\overline{0}$ & 4 & 0 & 4 & $\overline{0}$ & $\overline{4}$ & $\overline{0}$ & $\frac{4}{4}$ \\
\hline Sub Canopy grasses & & & & & & $-\ldots$ & $-($ no $r$ & & & . & - & & $-\cdots$ \\
\hline Digitaria cognata & DICO & 1.5 & 5.0 & 4.1 & 4.0 & 3.3 & 1.5 & 2.7 & 2.0 & 1.0 & - & 5.5 & 6.0 \\
\hline Eragrostis intermedia & ERIN & 5.6 & 3.0 & 1.1 & 5.6 & 3.5 & 5.0 & 2.2 & 1.7 & 3.0 & 1.3 & 4.1 & 2.4 \\
\hline Pappophorum vaginatum & PAVA & 1.7 & 0 & 1.0 & - & 20.2 & - & 5.0 & - & 1.3 & - & - & - \\
\hline Setaria leucopila & SELE & 4.2 & 5.0 & 3.9 & 7.0 & 2.3 & 1.3 & 3.8 & 4.0 & 2.5 & 3.5 & 2.8 & 1.0 \\
\hline Setaria texana & SETE & 3.0 & 2.2 & 2.2 & 3.8 & 4.3 & 3.5 & 6.0 & 3.3 & - & 1.2 & 2.0 & 2.8 \\
\hline Tridens eragrostoides & TRIN & 4.4 & 6.1 & 5.3 & 6.4 & 7.3 & 4.2 & 2.7 & 3.3 & 5.0 & 1.9 & 3.3 & 5.9 \\
\hline Tridens texanus & TRTE & 4.0 & 0 & 10.9 & 6.0 & 5.5 & - & 2.7 & - & 3.0 & - & 1.8 & - \\
\hline Chloris verticillata & CHVE & - & - & - & - & 1.0 & 1.0 & - & - & 4.0 & - & - & - \\
\hline Pappophorum bicolor & PABI & - & 5.7 & - & 6.0 & 1.0 & 11.0 & - & 6.0 & 1.0 & 12.0 & - & - \\
\hline Stipa leucotricha & STLE & 2.0 & 3.3 & 7.3 & 3.8 & 1.0 & - & - & 1.0 & 6.0 & 5.2 & - & 2.0 \\
\hline Eragrostis curtipedicellata & ERCU & - & 4.0 & - & 2.0 & - & 1.7 & - & - & - & 3.3 & - & - \\
\hline Chloris subdolichostachya & CHSU & - & - & - & - & - & - & - & - & 1.0 & - & - & - \\
\hline Schizachyrium scoparium & SCSC & - & 9.5 & - & - & - & - & - & - & - & - & - & - \\
\hline Bothriochloa pertusa & BOPE & - & 2 & 1.0 & - & - & 1.5 & - & - & - & - & - & - \\
\hline Hordeum pusillum & HOPU & - & - & - & - & - & - & - & - & 107 & - & - & - \\
\hline \multicolumn{14}{|l|}{ Interstitial grasses } \\
\hline Aristida purpurea & ARPU & 8.6 & 5.2 & 14.7 & 4.4 & 15.6 & 11.0 & 12.2 & 8.8 & 31.2 & 10.5 & 13.5 & 6.6 \\
\hline Bothriochloa saccharoides & BOSA & - & - & 1.0 & - & 1.3 & - & 2.0 & 7.0 & 1.0 & - & 1.0 & - \\
\hline Bouteloua trifida & BOTR & 68.2 & 8.1 & 33.2 & 4.2 & 44.0 & 6.6 & 27.4 & 14.3 & 31.4 & 8.2 & 39.4 & 8.9 \\
\hline Buchloe dactyloides & BUDA & 1.0 & 0 & 23.0 & - & - & - & 11.0 & - & - & - & 36.5 & - \\
\hline Hilaria belangeri & HIBE & 22.0 & 17.3 & 6.0 & 9.0 & 34.0 & - & 15.8 & 14.8 & 4.5 & 6.8 & 22.1 & 15.5 \\
\hline Sporobolus cryptandrus & SPCU & - & - & - & - & - & - & 1.0 & 1.0 & - & - & - & 2.0 \\
\hline Tridens muticus & TRMU & 7.9 & 6.9 & 24.3 & 7.8 & 6.2 & 7.4 & 5.8 & 4.0 & 15.7 & 3.2 & 5.9 & 3.6 \\
\hline Tridens albescens & TRAL & - & - & - & - & - & - & - & - & 5.0 & - & - & - \\
\hline Bouteloua rigidiseta & BORI & - & 1.8 & - & - & - & - & - & - & - & - & 3.0 & 1.5 \\
\hline Bothriochloa ischaemum & BOIS & - & - & - & - & - & 1.5 & - & - & - & - & - & - \\
\hline \multicolumn{14}{|l|}{ Both locations } \\
\hline Panicum hallii & PAHA & 3.1 & 1.4 & 4.7 & 1.4 & 4.6 & 1.0 & 3.6 & 1.7 & 4.2 & 1.0 & 3.1 & 2.0 \\
\hline Panicm obtusum & PAOB & - & 2.0 & 7.3 & 6.0 & 14.5 & 5.4 & - & 1.0 & - & - & - & - \\
\hline Bromus unioloides & BRUN & - & - & - & - & - & - & - & - & - & 4.0 & 1.0 & \\
\hline
\end{tabular}

al fuel allowed the fires to burn throughout the root crown and kill the tree. The loss of small trees and shrubs was not sufficient to cause a detectable change in woody plant canopy cover.

\section{Grasses}

Prior to treatment application, 33 species of grasses were identified in the permanent plots, with 5 occurring in trace amounts (Table 3 ). Only 2 species, little barley (Hordeum pusillum Nutt.) and rescuegrass (Bromus unioloides Kunth), were annuals, while the remainder were perennials. The grasses with the greatest density were Wrights threeawn (Aristida purpurea Nutt.), red grama (Bouteloua trifida Thurb.), and common curlymesquite (Hilaria berlangeri (Steud.) Nash). All 3 grasses were common in interstitial areas between mesquite trees and shrub clusters. Wrights threeawn and red grama are bunchgrasses and common curlymesquite is stoloniferous. Mid-grasses common under tree and shrub canopies included Texas bristlegrass (Setaria texana W.H.P. Emery), southwestern bristlegrass ( $S$. scheelei (Steud). A.S. Hitchc.), plains lovegrass (Eragrostis intermedia A.S. Hitchc.), and lovegrass tridens (Tridens eragrostoides (Vassey and Scribn.) Nash.).

Two eigenvectors were significant in the ordination ( $\mathrm{P}<0.1$, Fig $3 \mathrm{~A})$. Axis 1 (eigenvalue $=0.190$, length $=1.39$ ) represented a gradient away from species found in the interstitial spaces between mesquite trees [Wrights threeawn, red grama, curlymesquite and white tridens (Tridens albescens)] towards species found on moist sites [lovegrass tridens, vine mesquite (Panicum obtusum Kunth), and bristlegrass (Setaria leucopila Scribn. \& Merr.] (Fig. 3B). Axis 2 (eigenvalue = 0.111 , length 1.235 ) represented a movement from short-grasses towards mid-grass species found under mesquite trees [pink pappusgrass (Pappophorum bicolor Fourn.) and gummy lovegrass (Eragrostis curtipedicellata Buckl.)]. All of the plots showed a trajectory away from short grasses and towards mid-grasses over the course of the experiment (Fig 3A and B). The plots showing the greatest change were dominated by shortgrasses at the beginning of the experiment, but frequency of burning did not affect the trajectory of change.

\section{Forbs}

Eighty-eight forb species were found in more than a single permanent plot, and an additional 20 species occurred in only single plots (data not shown). Although 3 eigenvectors were significant, the first 2 accounted for most of the variation in forb cover (eigenvalues of 0.221 and 0.125 and lengths of 1.731 and 1.614 , respectively, Fig. 4). Species common on disturbed sites were found at low values of Axis 2 and high values of Axis 1 while forb species used as wildlife forage [Indianmallow (Abutilon fruticosum Pen. \& Rich.), Leatherweed croton (Croton pottsii. L.), slender fleabane (Erigeron tenuis L.)] were found at high values of both Axis 1 and Axis 2. There were no discernible patterns to the trajectories of forb cover due to either season or frequency of burning (Fig. 4). Forb composition appeared to be more affected by year effects than by any treatment. Observations from each year tended to group together regardless of burning treatment. 


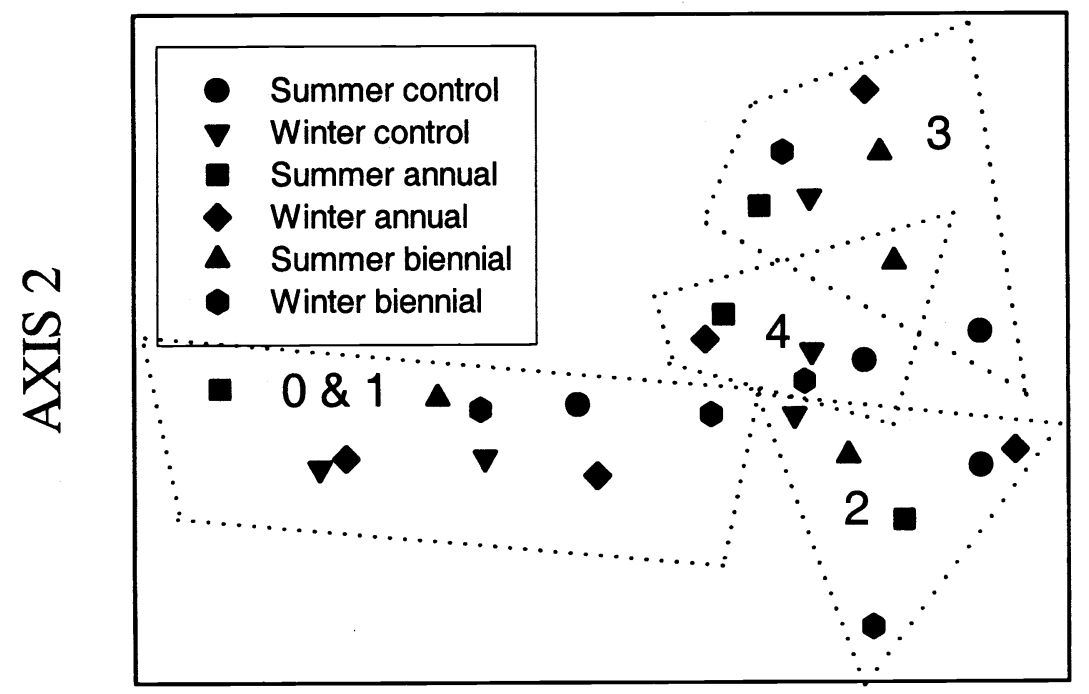

\section{AXIS 1}

Fig. 4. Detrended correspondence analysis of forb cover within a mesquite/mixed acacia shrubland in the Rio Grande Plains of Texas after growing-season (GS) and dormant-season (DS) fires. Numbers within the figure designate the year of observation beginning in 1990.

\section{Grass population structure}

Single fires, whether conducted during the dormant or growing season, did not affect the distribution among size classes of perennial grasses (Fig. 5, treatment by observation interaction term; $\mathrm{F}_{1,8}=1.84$ and $\mathrm{F}_{1,8}=0.16$, dormant and growing season, respectively). Fewer small plants $\left(<25 \mathrm{~cm}^{2}\right)$ occurred on burned plots after the fires, but they also decreased on the control plots. The number of mediumsized and large plants was low and remained constant on all treatments over the 2 years.

Burning in 2 successive years did not change the size class distribution of grasses compared to burning in a single year, or to not burning at all during either the growing-season (fire frequency by time interaction, $\mathrm{F}_{4,8}=0.67$ ), or the dormantseason (fire frequency by time interaction, $\mathrm{F}_{4,8}=0.73$ ). The density of small plants decreased in all treatments, but the number of medium-sized plants increased at the same time (data not shown). This suggests that plants were simply growing from one size class to another, regardless of the season or frequency of fire.

Recurring fires, where plots were burned every year for 4 years or burned every other year for 4 years, did not affect the size class distribution of grasses (fire frequency by time interaction, $\mathrm{F}_{6,11}=0.89$ and $F_{6,11}=0.74$ for growing-season and dormant-season fires, respectively). Plant densities were greatest in the small size class and approximately equal for the medium-sized and large plants among all treatments.

\section{Discussion}

Growing season fires typically generate more heat with greater flame length, rate of spread, and fireline intensity than dormant season fires (Sapsis and Kauffman 1991, Ansley et al. 1995, Williams et al. 1999). These growing season fires directly alter the plant's environment by increasing soil hardness, decreasing surface soil water content, and increasing soil temperatures through increased radiation loads (Daowei and Ripley 1997). In addition, fires which occur when the plant is physiologically active should be more likely to damage a plant than when the plant is dormant (Daubenmire 1968). It would seem therefore that growing season fires should have more of an effect than dormant season fires on community stability and succession. In fact, growing season fires can increase germination of some woody species (Hodgkinson 1991) and may promote herbaceous species diversity in some instances (Howe 1994, 1995). In this study, however, there was no change in the number of forb species following either growing-season or dormant-season fires as compared to unburned controls. There are 2 possible explanations for this observation. First, the number of forb species was already high with over 100 species found in this 80-ha area, so an increase in diversity was unlikely; or second, the forb component of this ecosystem is driven more by annual weather patterns than by occasional disturbances such as fire. The grouping of the years of observations in the ordination space (Fig. 4) suggests that annual weather patterns were probably the driving variable for the forb component of this community.

Most of the grasses on this study site were $\mathrm{C} 4$ grasses, with the exception of Texas wintergrass (Stipa leuchotricha Trin \& Rupr.) and little barley. Short-grasses were spatially limited to the interstital areas while mid-grasses were common under the canopies of mature mesquite trees. Neither growing-season nor dormant-season fires caused a shift in the distribution of size classes among the grasses. Most of the grass population (93\%) was in the $<25 \mathrm{~cm}^{2}$ basal area class, and changes were only noted when plants grew into the next larger size class. All plots, burned and unburned, showed a trajectory from short-grasses to mid-grasses over the 5 year study. The control and biennial burning cycle of the dormant season treatments had the greatest shift in composition towards mid-grasses as evidenced by the greatest Euclidean distance between the beginning and end of the experiment in the ordinations (Fig 3A). These areas were generally in lower ecological condition than other areas at the beginning of the experiment. The changes in the grass component were more likely due to the absence of livestock grazing over a 5 year period than from any of the fire regimes. This area had been used as a trap for holding livestock and was heavily grazed prior to this study. The observation that burned and control treatments experienced similar dynamics, supports the hypothesis of a grazing release effect.

Single or recurring fires rarely decrease the density or abundance of resprouting shrubs and trees (Grice 1997, Ansley and Jacoby 1998, Sparks et al. 1998, Pendergrass et al. 1998). We observed little mortality of shrubs within the burned areas and there was little movement in the ordination space (Fig 2A). The shrub component remained at about the same composition from the beginning to the end of the experiment. The stability of the shrub component was similar to reports from a variety of different ecosystems including 


\section{Growing Season Dormant Season}

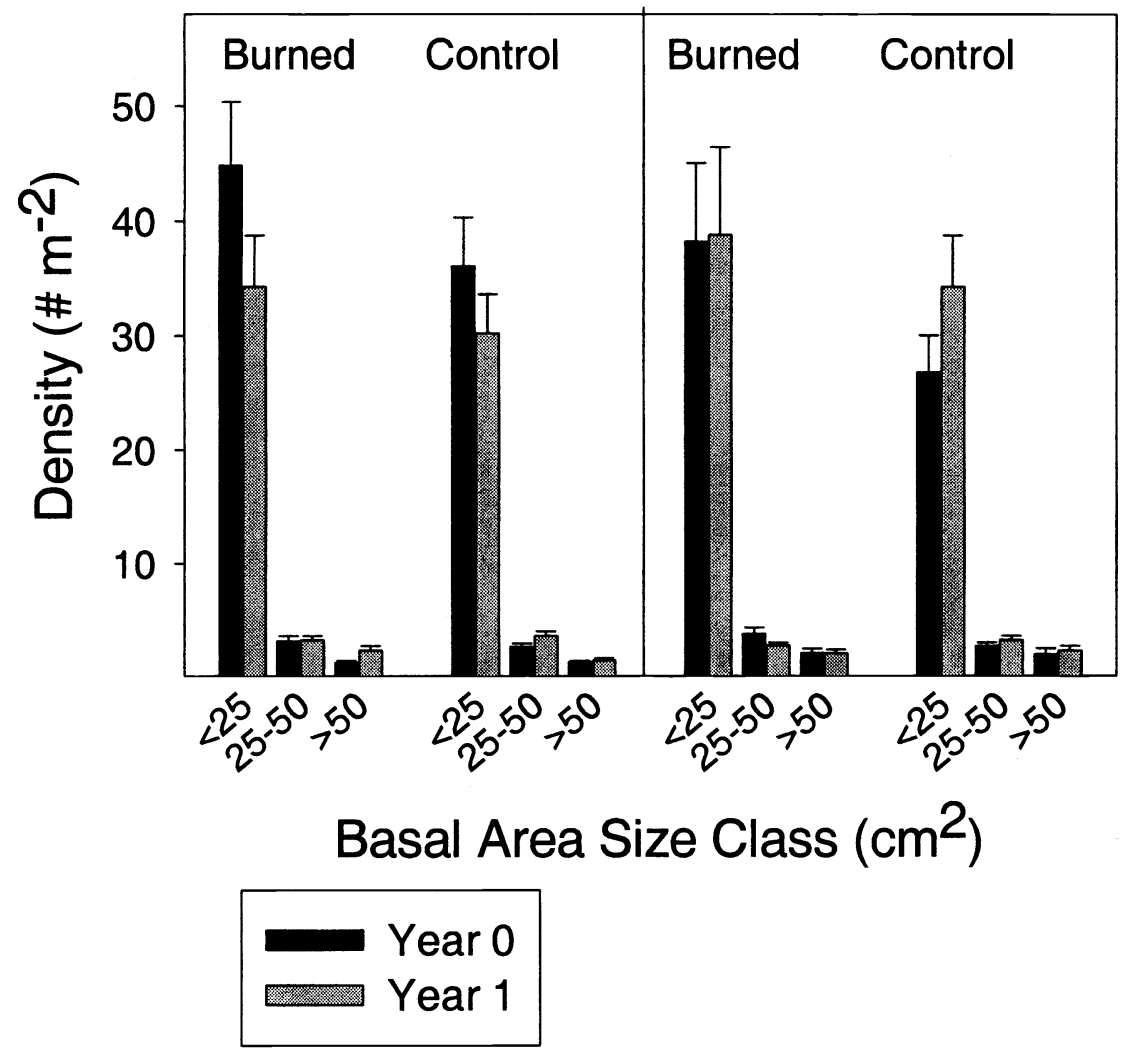

Fig. 5. The distribution of perennial grasses among 3 basal area size classes following growing-season and dormant-season prescribed fires in a mesquite/mixed acacia shrubland in the Rio Grande Plains of Texas. Year 0 refers to the samples prior to the prescribed fires (1990) and Year 1 is the first growing season after the fires (1991). Control plots were not burned. Error bars denote $\pm 1 \mathrm{SE}$.

short-leaf pine (Pinus echinata) communities (Sparks et al. 1998), Willamette Valley prairies (Pendergrass et al. 1998), north Australian woodlands (Grice 1997), and Sierra Nevada mixed conifers (Kauffman and Martin 1990). In all of these plant communities, plant mortality was generally $<10 \%$ for resprouting species although stem mortality was somewhat higher than that.

Fire frequency was expected to accelerate grass and forb composition change, but not expected to alter shrub composition (Ansley and Jacoby 1998). Our annual burn cycle was meant to mimic the most severe fire cycle, but we found no differences in grass density or forb cover between the annual and biennial fire cycles. Burning annually would require grazing restrictions to accumulate fine fuel, but plant responses would still mimic those of the biennial fire cycle.

Our findings may be related more to fire intensity than to frequency or seasonality.
High intensity fires cause more bare ground and greater recruitment (Hodgkinson 1991), and may have a more severe impact on plant population dynamics. Fuel loads on this site were low (450 to $890 \mathrm{~kg} \mathrm{ha}^{-1}$ ), but more importantly they were discontinuous so the rate of spread was low. The fires were therefore low intensity fires (although fireline intensity was not measured) which may kill small shrubs and low branches on large shrubs or trees (Ansley and Jacoby 1998), but should not alter shrub community composition. The relative importance of fire intensity rather than fire season has also been demonstrated in longleaf pine savannas in Florida (Glitzenstein et al. 1995) and in oak woodland in Oklahoma (Engle et al. 1996).

Reintroducing growing season fires into mesquite/mixed acacia shrublands did not conclusively alter plant community composition. Movement from a short-grass dominated site to mid-grasses was evident in both burned and unburned plots suggesting that the cessation of grazing for 5 years was an important factor. When compared to the ungrazed controls, burning during the growing season with hotter and drier conditions did not accelerate change to a grass dominated community. We suggest that annual or biennial burns, either during the growing season or the dormant season, are not effective tools for stimulating the conversion of a shrubland to a grassland in the mesquite/mixed acacia savannas of south Texas.

\section{Literature Cited}

Abrahamson, W.G. and J.R. Abrahamson. 1996. Effects of a low-intensity winter fire on long-unburned Florida sand pine scrub. Natural Areas J. 16:171-183

Ansley, R.J. and P.W. Jacoby. 1998. Manipulation of fire intensity to achieve mesquite management goals in north Texas. Pages 195-204 In: T.L. Pruden and L.A. Brennan (eds.). Fire in ecosystem management: shifting the paradigm from suppression to prescription. Tall Timbers Fire Ecology Conference Proceedings, No. 20. Tall Timbers Research Station, Tallahassee, Fla.

Ansley, R.J., B.A. Kramp, and T.R. Moore. 1995. Development and management of mesquite savanna using low intensity prescribed fires. Proc. Fire Effects on Rare and Endangered Species and Habitats Conference. Couer d'Alene, Ida.

Biondini, M. E., A.A. Steuter, and. C.E. Grygiel. 1989. Seasonal fire effects on the diversity patterns, spatial distribution and community structure of forbs in the northern mixed prairie, USA. Vegetatio 85:21-31.

Boo, R. M., D.V. Pelaez, S.C. Bunting, M.D. Mayor, and O.R. Elia. 1997. Effect of fire on woody species in central semi-arid Argentina. J. Arid Environ. 35: 87-94.

Canfield, R.H. 1941. Application of the lineintercept method in sampling range vegetation. J. Forest. 39:388--394.

Daowei, Z. and E.A. Ripley. 1997. Environmental changes following burning in a Songnen grassland, China. J. Arid Environ. 36:53-65.

Daubenmire, R. 1968. Ecology of fire in grasslands. Adv. in Ecol. Res. 5:209-266.

Engle, D.M., T.G. Bidwell, and R.E. Masters. 1996. Restoring Cross Timbers ecosystems with fire. Trans. $61^{\text {st }}$ No. Amer. Wild. and Natur. Resour. Conf. Pp.190-199.

Engle, D.M., J.F. Stritzke, and F.T. McCollum. 1991. Vegetation management in the Cross Timbers: Response of understory vegetation to herbicides and burning. Weed Tech. 5:405-410.

Fuhlendorf, S.D. and F.E. Smeins. 1997. Long-term vegetation dynamics mediated by herbivores, weather and fire in a JuniperusQuercus savanna. J. Veg. Sci. 8:819-828. 
Glitzenstein, J.S., W.J. Platt, and D.R. Streng. 1995. Effects of fire regime and habitat on tree dynamics in north Florida lonfleaf pine savannas. Ecol. Monog. 65:441-476.

Gosz, R.J. and J.R. Gosz. 1996. Species interactions on the biome transition zone in New Mexico: response of blue grama (Bouteloua gracilis) and black grama (Bouteloua eripo$d a)$ to fire and herbivory. J. Arid Environ. 34:101-114.

Grice, A. C. 1997. Post-fire regrowth and survival of the invasive tropical shrubs Cryptostegia grandiflora and Ziziphus mauritiana. Australian J. Ecol. 22:49-55.

Hatch, S.L., K.N. Gandhi, and L.E. Brown. 1990. Checklist of the vascular plants of Texas. Texas Agr. Exp. Sta. MP-1655, College Station, Tex.

Hill, M.O. and H.G. Gauch, Jr. 1980. Detrended correspondence analysis, an improved ordination technique. Vegetatio 42:45-58.

Hodgkinson, K. C. 1991. Shrub recruitment response to intensity and season of fire in a semi-arid woodland. J. Applied Ecol. 28:60-70.
Howe, H. F. 1994. Managing species diversity in tallgrass prairie: Assumptions and implications. Conserv. Biol. 28: 691-704.

Howe, H. F. 1995. Succession and fire season in experimental prairie plantings. Ecol. 76: $1917-1925$.

Howe, H.F. 2000. Grass response to seasonal burns in experimental plantings. J. Range Manage. 53:437-441.

Kauffman, J. B. and R.E. Martin. 1990. Sprouting shrub response to different seasons and fuel consumption levels of prescribed fire in sierra nevada mixed conifer ecosystems. Forest Sci. 36: 748-764.

Mead, R. 1988. The Design of Experiments: Statistical principles for practical application. Cambridge University Press, New York, N.Y..

Milliken, G.A. and D.E. Johnson. 1989. Analysis of Messy Data. Volume 2. Nonreplicated Experiments. Chapman and Hall, New York, N.Y.

Pendergrass, K.L., P.M. Miller, and J.B. Kauffman. 1998. Prescribed fire and the response of woody species in Willamette Valley wetland prairies. Restoration Ecol. 3:303-311.
Sapsis, D. B. and J. B. Kauffman. 1991. Fue consumption and fire behavior associated with prescribed fires in sagebrush ecosystems. Northwest. Sci. 65: 173-179.

Scifres, C.J. and W.T. Hamilton. 1993. Prescribed burning for brushland management. Texas A\&M University Press, College Station, Tex.

Sparks, J.C., R.E. Masters, D.M. Engle, M.W. Palmer, and G.A. Bukenhofer. 1998. Effects of late growing-season and late dormant-season prescribed fire on herbaceous vegetation in restored pine-grassland communities. J. Veg. Sci. 9:133-142.

Tveten, R.K. and R.W. Fonda. 1999. Fire effects on prairies and oak woodlands on Fort Lewis, Washington. Northwest Sci. 73:145-158.

Williams, R.J., G.D. Cook, A.M. Gill, and P.H.R. Moore. 1999. Fire regime, fire intensity and tree survival in a tropical savanna in northern Australia. Aust. J. Ecol. 24:50-59. 